\title{
Integrated continuous winemaking process involving sequential alcoholic and malolactic fermentations with immobilized cells
}

\author{
Z. Genisheva*, A. Mota, S.I. Mussatto, J.M. Oliveira, J.A. Teixeira \\ IBB-Institute for Biotechnology and Bioengineering, Centre of Biological Engineering, Universidade do Minho, 4710-057 Braga, Portugal
}

\section{A R T I C L E I N F O}

\section{Article history:}

Received 17 July 2013

Received in revised form

25 September 2013

Accepted 12 October 2013

Available online 22 October 2013

\section{Keywords:}

Continuous winemaking

Immobilized cells

Aroma compounds

Packed bed reactor

\begin{abstract}
A B S T R A C T
An integrated winemaking process - including sequential alcoholic and malolactic fermentations operated continuously - was developed. For the continuous alcoholic fermentation, yeast cells (Saccharomyces cerevisiae) were immobilized either on grape stems or on grape skins, while bacterial cells (Oenococcus oeni) used for conducting continuous malolactic fermentation were immobilized on grape skins only. The produced wines were subjected to chemical analysis by HPLC (ethanol, glycerol, sugars and organic acids) and by gas chromatography (major and minor volatile compounds). The final proposed integrated continuous process permitted the production of $960 \mathrm{~mL} / \mathrm{d}$ of a dry white wine, with an alcoholic strength of about $13 \mathrm{vol} \%$, by using two $1.5 \mathrm{~L}$ tower bed reactors packed with $260 \mathrm{~g}$ of grape skins. The produced wines revealed a good physicochemical quality. Moreover, $67 \%$ of the malic acid concentration could be reduced in the second reactor. Both fermentative processes proved to be much more efficient than those conducted traditionally with free cells or even with immobilized cells, but in the batch mode of operation.
\end{abstract}

(C) 2013 Elsevier Ltd. All rights reserved.

\section{Introduction}

The two most important processes in wine production are alcoholic fermentation (AF), conducted by yeasts, and malolactic fermentation (MLF), conducted by bacteria. During the alcoholic fermentation the sugars of grape must are transformed mainly to ethanol and carbon dioxide; additionally, a myriad of by-products are formed. Malolactic fermentation is a secondary fermentation that reduces the acidity and brings biological stability to the wines; moreover, it improves the organoleptic characteristics of the product [1].

In traditional winemaking the fermentation processes are conducted in discontinuous mode, i.e. in batch. The seasonality of the raw-material, the grapes, defines largely the organization of this sector of activity and also the structure of the wine cellars. Nevertheless, continuous processes are known to be advantageous over batch processes. The continuous process is simpler to operate with low energy requirements, allowing almost complete utilization of the substrates and lowering the operating costs. Moreover, capital costs are reduced, with the possibility to obtain higher rates of production by using small bioreactors in the process. Superior productivities may be achieved by employing high concentrations of yeast or bacterial cells within the bioreactor.

\footnotetext{
* Corresponding author. Tel.: +351253 604 411/+351253604 400; fax: +351253604 429.

E-mail address: zgenisheva@gmail.com (Z. Genisheva).
}

However, a conventional continuous process has limitations in the maintenance of high cell concentrations in the bioreactor [2]. To overcome this difficulty, immobilized yeast or bacteria cell systems provide high cell density with high flow rates that results in short residence times [3]. Reactors with immobilized cells have shorter fermentation times, higher productivity and operational stability of the cells, as well as easier downstream processing.

When dealing with immobilized cell systems it is of a big importance to choose the proper reactor type. This decision depends on the type of immobilization and type of support used, as well as on mass transfer requirements and conditions of the process. For continuous AF in wine production, multiphase reactors are used, including packed bed reactor, fluidized bed reactor, bubble column and air-lift reactor $[3,4]$. Packed bed reactor is among the most used for wine production with immobilized cells in continuous mode of operation $[5,6]$. In this type of reactor the immobilized cells are packed inside the reactor and a current of fermentation media is passed upflow (flooded bed reactor) or downflow (trickle-bed reactor) [7].

Most of the available data published about immobilized cell systems used in winemaking concerns batch processes, and in a less extent continuous alcoholic fermentation. Natural materials such as fruit pieces of apple, quince, pear, guava and watermelon $[5,6,8-10]$, whole grains of corn, wheat and barley [11-13] or residues of the wine industry $[14,15]$ are reported as supports for cell immobilization and further implied in batch winemaking. Most of these immobilized cell systems were found to be of good operational stability. In continuous alcoholic fermentation, 
for winemaking, the used yeast cells are frequently immobilized on natural organic and inorganic materials. Immobilized cell systems using natural organic materials such as gluten pellets resulted in wines with improved quality [16]. Inorganic materials like kissiris and $\gamma$-alumina, are cheap, abundant and can be regenerated and reused, however this materials were considered undesirable as they leave mineral residues in the final product $[17,18]$.

The immobilization methods mostly used for bacteria cell immobilization in malolactic fermentations are entrapment [19] and attachment to natural materials [20,21]. There are few available articles on the continuous malolactic fermentation of wines conducted with immobilized cells [22]. Moreover, according to what we know so far no works were published about an integrated continuous process of winemaking.

The main objective of this study was the integration of both alcoholic fermentation (AF) and malolactic fermentation (MLF) in a sequential continuous winemaking process. To achieve this global goal, both AF and MLF were implemented in distinct packed bed reactors operating with immobilized Saccharomyces cerevisiae and Oenococcus oeni, respectively.

\section{Materials and methods}

\subsection{Inocula preparation}

A commercial S. cerevisiae strain (Lalvin QA23 ${ }^{\circledR}$, Lallemand) was used in the alcoholic fermentation experiments. The inoculum was prepared by cultivation of the yeast in $500 \mathrm{~mL}$ Erlenmeyer flasks containing $200 \mathrm{~mL}$ of YPD medium with the following composition: yeast extract $(10 \mathrm{~g} / \mathrm{L})$, peptone $(20 \mathrm{~g} / \mathrm{L})$ and glucose $(20 \mathrm{~g} / \mathrm{L})$. Cells were cultivated under static conditions, at $30^{\circ} \mathrm{C}$ for $24 \mathrm{~h}$, being subsequently recovered by centrifugation $(R C F=7000,20 \mathrm{~min})$, washed with distilled water and resuspended in the fermentation medium to obtain an initial concentration of $1 \mathrm{~g} / \mathrm{L}$ (dry weight).

A commercial strain of 0 . oeni (Uvaferm ${ }^{\circledR}$ ALPHA, Lallemand) was the bacterial strain used in the malolactic fermentation experiments. The inoculum was prepared by cultivation of the bacteria in $500 \mathrm{~mL}$ Erlenmeyer flasks containing $200 \mathrm{~mL}$ of MRS Broth medium (Cultimed, Panreac, Barcelona). Cells were cultivated under static conditions, at $28^{\circ} \mathrm{C}$ for $48 \mathrm{~h}$, being subsequently recovered by centrifugation $(R C F=7000,10 \mathrm{~min})$, washed with distilled water and resuspended in the fermentation medium to obtain an initial concentration of $1 \mathrm{~g} / \mathrm{L}$ (dry weight).

\subsection{Support materials for cell immobilization}

Grape skins and grape stems (from white grape varieties), separately, were used as support materials for cell immobilization. These supports were supplied by a local winemaking company, being washed with distilled water and dried at $60^{\circ} \mathrm{C}$ until constant weight. Then, supports were sterilized for $20 \mathrm{~min}$ at $121^{\circ} \mathrm{C}$, before use.

\subsection{Media composition for fermentation assays}

Complex culture medium used in the alcoholic fermentation assays was composed by glucose $(120 \mathrm{~g} / \mathrm{L})$, yeast extract $(4 \mathrm{~g} / \mathrm{L})$, $\left(\mathrm{NH}_{4}\right)_{2} \mathrm{SO}_{4}(1 \mathrm{~g} / \mathrm{L}), \mathrm{KH}_{2} \mathrm{PO}_{4}(1 \mathrm{~g} / \mathrm{L})$ and $\mathrm{MgSO}_{4}(5 \mathrm{~g} / \mathrm{L})$. Complex culture medium used in the malolactic fermentation had the following composition: glucose $(15 \mathrm{~g} / \mathrm{L})$, yeast extract $(4.0 \mathrm{~g} / \mathrm{L})$, meat extract $(8.0 \mathrm{~g} / \mathrm{L})$, bacteriological peptone $(10.0 \mathrm{~g} / \mathrm{L}), \mathrm{MgSO}_{4}(0.2 \mathrm{~g} / \mathrm{L})$, $\mathrm{MnSO}_{4}(0.05 \mathrm{~g} / \mathrm{L})$, sodium acetate $(5.0 \mathrm{~g} / \mathrm{L})$, tween $80(1.0 \mathrm{~g} / \mathrm{L})$, dipotassium hydrogen phosphate $(2.0 \mathrm{~g} / \mathrm{L})$, di-ammonium hydrogen citrate $(2.0 \mathrm{~g} / \mathrm{L})$ and malic acid $(4.0 \mathrm{~g} / \mathrm{L})$.

The grape must used for alcoholic fermentations was obtained from a mixture of white grape varieties from the Appellation of

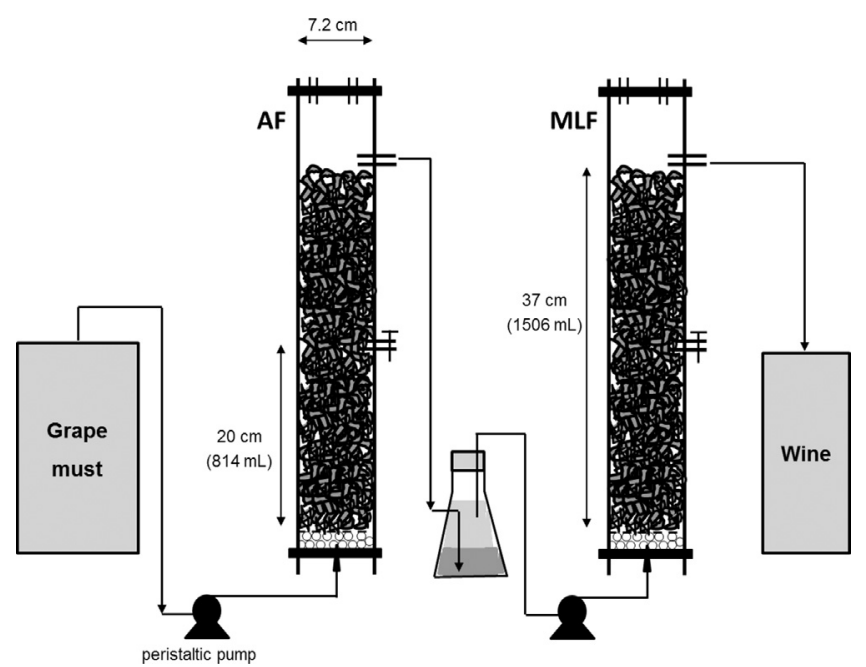

Fig. 1. Schematic representation of the integrated process of continuous winemaking.

Origin Vinhos Verdes region, with a total sugar content of $\approx 200 \mathrm{~g} / \mathrm{L}$, quantified by areometry [26]. The used wines for malolactic fermentation were produced in laboratory conditions and had an initial concentration of malic acid around $4 \mathrm{~g} / \mathrm{L}$. The grape must and wine were kept at $4{ }^{\circ} \mathrm{C}$, before use. Initially, the studies were conducted with complex medium and later grape must and wine were used for alcoholic and malolactic fermentations, respectively. The choice of complex medium in the initial fermentations avoided difficulties with the supply and storage of grape must. Initially, the glucose content of the complex media (used in the alcoholic fermentation) was $120 \mathrm{~g} / \mathrm{L}$ for a better and faster immobilization of the yeast cells.

\subsection{Reactors preparation}

Continuous alcoholic and malolactic fermentation assays were performed in distinct cylindrical tower packed bed reactors $(7.2 \mathrm{~cm}$ inside diameter) with a total volume of about $1750 \mathrm{~mL}$. Two sampling ports were available at $20 \mathrm{~cm}$ and $37 \mathrm{~cm}$ height, corresponding to working volumes (volume of the empty bed), of $814 \mathrm{~mL}$ and $1506 \mathrm{~mL}$, respectively (Fig. 1). Both reactors were operated in upward flow mode.

Before use, the reactors were sterilized with sodium hypochlorite solution ( $1.5 \%$ active chlorine) during at least $4 \mathrm{~d}$ prior to fermentations [23]. Then, the reactors were washed with five volumes of sterilized water before filling with the sterilized support. At the bottom of each reactor, $1 \mathrm{~cm}$ height of glass beads $(6 \mathrm{~mm}$ diameter) was placed to allow a regular repartition of the feeding medium in the whole section of the tower. Then, the reactor for continuous alcoholic fermentation was packed with grape stems $(60 \mathrm{~g}$ or $90 \mathrm{~g}$ ) or with grape skins ( $125 \mathrm{~g}$ or $260 \mathrm{~g}$ ) in sterile conditions in the flow chamber. Similarly, the packed bed reactor for continuous malolactic fermentation was filled in with $260 \mathrm{~g}$ of grape skins. The assays with $60 \mathrm{~g}, 90 \mathrm{~g}$ and $125 \mathrm{~g}$ of material were carried out using the first sampling port, i.e. at $20 \mathrm{~cm}$ height; the assays with $260 \mathrm{~g}$ of support were performed using the total available volume at $37 \mathrm{~cm}$ height. The supports were restricted with an iron nets placed above the glass beads and above the support itself.

\subsection{Fermentation assays}

A schematic representation of the assays carried out in the present study is depicted in Fig. 2. Initially, for cells immobilization, the reactors were operated in batch mode. The reactors were 


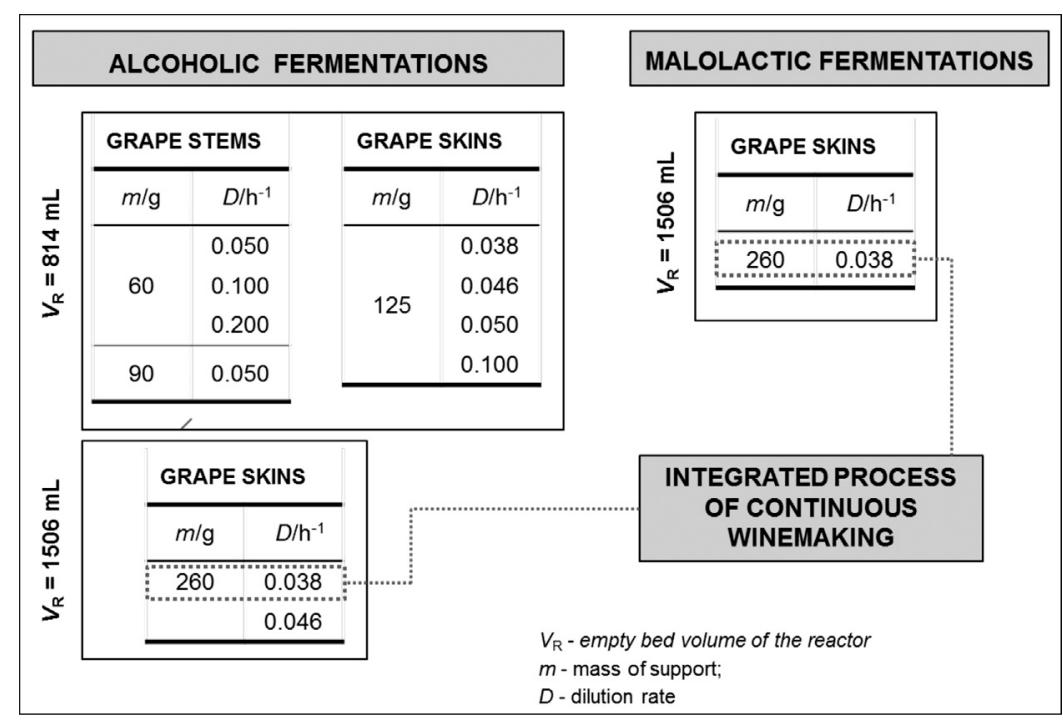

Fig. 2. Experimental design of the continuous fermentation assays conducted with immobilized cells.

charged with $1 \mathrm{~L}$ of complex medium and about $50 \mathrm{~mL}$ of yeast or bacterial cell suspension prepared as described in the inocula preparation subsection. Then, after $48 \mathrm{~h}$ of immobilization in batch mode, the reactors were switched to a continuous mode, and operated at different dilution rates (Fig. 2). After all the operational conditions of the reactors were established and the processes were stabilized, the complex medium was replaced by grape must for alcoholic fermentation, and wine for malolactic fermentation. Continuous AF and MLF were conducted initially in separate. After optimization of the processes conditions the two reactors were linked together.

All analyses were made in duplicate after the stationary state of the continuous process was attained.

\subsection{Free and immobilized cells determination}

Immobilized yeast cells concentration was determined by counting the yeast cells on a Neubauer chamber at the fermentations' end after washing the biocatalyst by agitation $\left(120 \mathrm{~min}^{-1}\right)$ with $30 \mathrm{~g} / \mathrm{L} \mathrm{NaOH}$ solution, for $24 \mathrm{~h}$ at $30^{\circ} \mathrm{C}$, according to Genisheva et al. [24].

Death/live cells were determined after detachment of the cells by vigorous agitation of $0.5 \mathrm{~g}$ of the support with $30 \mathrm{~g} / \mathrm{L}$ solution of $\mathrm{NaCl}$, for $30 \mathrm{~min}$. Then, the liberated cells were further stained with methylene blue and the dead/live cells were counted on a Neubauer chamber.

The concentration of immobilized bacterial cells was determined at the end of fermentation assays. About $3.5 \mathrm{~g}$ of material (wet weight) were placed in a $200 \mathrm{~mL}$ Erlenmeyer flask containing $20 \mathrm{~mL}$ of distilled water. Subsequently, it was autoclaved for $20 \mathrm{~min}$ at $121^{\circ} \mathrm{C}$. The autoclaved support was separated from the liquid using a strainer and left to dry at $60^{\circ} \mathrm{C}$ till constant weight. The total volatile suspended solids, remained in water, were determined by gravimetry according to Clesceri et al. [25]. A blank experiment using support without immobilized cells was used to correct eventual losses of material during the autoclaving procedure.

Free yeast and bacterial cells concentrations, present in the fermentation medium, were estimated by measuring the absorbance at $600 \mathrm{~nm}$, which was correlated to a calibration curve (dry weight $\times$ absorbance).

\subsection{Fermentation parameters}

The concentration of immobilized cells $\left(X_{\mathrm{im}}\right)$ was calculated as the ratio of the dry weight of cells to the dry weight mass of the support. The mass concentrations of malic acid $\left(C_{\text {mal.ac }}\right)$, lactic acid $\left(C_{\text {lac.ac }}\right)$ and acetic acid $\left(C_{\text {acet.ac }}\right)$ were calculated respectively as the ratio of the mass of malic acid, lactic acid and acetic acid, per liter of fermentation medium. The conversion of malic acid $\left(\eta_{\text {mal.ac }}\right)$ was determined as the ratio between the consumed malic acid and the initial malic acid. The mass concentrations of glucose $\left(C_{\mathrm{gl}}\right)$ and fructose $\left(C_{\mathrm{fr}}\right)$ were calculated as the mass of glucose and fructose per liter of fermentation medium. The alcohol strength $\left(C_{\mathrm{et}}\right)$ was calculated as the volume of ethanol present in 100 volumes of the fermentation product. The dilution rate $(D)$ was defined as the ratio between the volumetric flow rate and the liquid phase volume of the packed reactor.

\subsection{General physicochemical analysis}

Total acidy (TA) and free $\mathrm{SO}_{2}$ concentration were measured by titration according to the Methods OIV-MA-AS313-01 and OIV-MAAS323-04A, respectively [26].

\subsection{HPLC analysis}

Glucose, fructose, ethanol, glycerol and organic acids (citric, tartaric, malic, succinic lactic and acetic) concentrations were determined by high performance liquid chromatography (HPLC) in a Jasco chromatograph equipped with a refractive index detector (Jasco 830-RI), an ultraviolet detector (Jasco UV-2070) and a Varian Metacarb $67 \mathrm{H}$ column $(300 \mathrm{~mm} \times 6.5 \mathrm{~mm})$ operated at $80^{\circ} \mathrm{C}$. A $5 \mathrm{mmol} / \mathrm{L} \mathrm{H}_{2} \mathrm{SO}_{4}$ solution was used as eluent at a constant flow rate of $0.3 \mathrm{~mL} / \mathrm{min}$. These analyses were made in duplicate. The quantification of each compound was made by using a calibration curve (peak area vs. concentration).

\subsection{Gas-chromatographic analysis}

Major volatile compounds were directly analyzed after adding $410 \mu \mathrm{g}$ of 4 -nonanol (internal standard-IS) to $5 \mathrm{~mL}$ of wine. A Chrompack CP-9000 gas chromatograph equipped with a split/splitless injector, a flame ionization detector (FID) and 
a capillary column, coated with CP-Wax $57 \mathrm{CB}(50 \mathrm{~m} \times 0.25 \mathrm{~mm}$; $0.2 \mu \mathrm{m}$ film thickness, Chrompack), was used. The temperatures of the injector and the detector were both set to $250^{\circ} \mathrm{C}$. The oven temperature was initially held at $60^{\circ} \mathrm{C}$, for $5 \mathrm{~min}$, then programmed to rise from $60^{\circ} \mathrm{C}$ to $220^{\circ} \mathrm{C}$, at $3^{\circ} \mathrm{C} / \mathrm{min}$, and finally maintained at $220^{\circ} \mathrm{C}$ for $10 \mathrm{~min}$. The carrier gas was helium $4 \times$ (Praxair) at an initial flow rate of $1 \mathrm{~mL} / \mathrm{min}(125 \mathrm{kPa}$ at the head of the column). The analyses were performed by injecting $1 \mu \mathrm{L}$ of sample in the split mode $(15 \mathrm{~mL} / \mathrm{min})$. The quantification of major volatile compounds, after the determination of the detector response factor for each analyte, was performed with the software StarChromatography Workstation version 6.41 (Varian) by comparing test compound retention times with those of pure standard compounds.

Minor volatile compounds were analyzed by GC-MS after extraction of $8 \mathrm{~mL}$ of wine with $400 \mu \mathrm{L}$ of dichloromethane, spiked with $3.28 \mu \mathrm{g}$ of 4-nonanol (IS), according to the methodology proposed by Oliveira et al. [27]. A gas chromatograph Varian 3800 with a 1079 injector and an ion-trap mass spectrometer Varian Saturn 2000, was used. A $1 \mu \mathrm{L}$ injection was made in splitless mode ( $30 \mathrm{~s}$ ) in a Varian Factor Four VF-Wax ms $(30 \mathrm{~m} \times 0.15 \mathrm{~mm}$; $0.15 \mu \mathrm{m}$ film thickness) column. The carrier gas was helium $4 \times$ (Praxair) at a constant flow rate of $1.3 \mathrm{~mL} / \mathrm{min}$. The detector was set to electronic impact mode with an ionization energy of $70 \mathrm{eV}$, a mass acquisition range from $35 \mathrm{~m} / z$ to $260 \mathrm{~m} / \mathrm{z}$ and an acquisition interval of $610 \mathrm{~ms}$. The oven temperature was initially $60^{\circ} \mathrm{C}$ for $2 \mathrm{~min}$ and then raised from $60^{\circ} \mathrm{C}$ to $234^{\circ} \mathrm{C}$ at a rate of $3^{\circ} \mathrm{C} / \mathrm{min}$, raised from $234^{\circ} \mathrm{C}$ to $250^{\circ} \mathrm{C}$ at $10^{\circ} \mathrm{C} / \mathrm{min}$ and finally maintained at $250^{\circ} \mathrm{C}$ for $10 \mathrm{~min}$. The temperature of the injector was maintained at $250^{\circ} \mathrm{C}$ during the analysis time and the split flow was maintained at $30 \mathrm{~mL} / \mathrm{min}$. The identification of compounds was performed using the software MS WorkStation version 6.9 (Varian) by comparing their mass spectra and retention indices with those of pure standard compounds. The minor compounds were quantified in terms of 4-nonanol equivalents only. licate.

\subsection{Statistical analysis}

The results were analyzed by ANOVA, using FAUANL software [28]. Fisher's Least Significance Difference (LSD) multiple comparison test was used to detect significant differences $(p<0.05)$ between samples.

\section{Results and discussion}

In previous studies, Genisheva et al. [14,21] showed the possibility of conducting, in batch mode of operation, alcoholic and malolactic fermentations with $S$. cerevisiae and $O$. oeni cells immobilized either on grape stems or on grape skins. The present study evaluated the possibility of conducting the same fermentations processes but in a continuous mode of operation. In the first part of this work, studies with immobilized yeast cells to carry out the AF for white wine production were made. Different amounts of two different supports (grape stems and grape skins) were used, and the system was operated at different dilution rates. Grape skins and grape stems were chosen as supports on the bases of two previous studies where different materials for the immobilization of yeast and bacterial cells were analyzed $[21,24]$. In the second part, assays with immobilized bacteria cells for malolactic fermentation of white wine, were conducted. Finally, the integration of the two continuous fermentative processes, in a whole winemaking procedure, was studied.

\subsection{Continuous alcoholic fermentations}

There are limited published data about the production of wines by continuous alcoholic fermentation with immobilized cells. Moreover, only a few works are concerning the use of natural materials, like pieces of fruits, for the immobilization of the yeast cells $[5,6,8]$. Even though the pieces of fruits are appropriate for winemaking, their cultivation, availability and cost are limited for industrialization [10]. In the present work were used residues from the wine industry (grape stems and grape skins), that are normally available in large amounts and have low cost. Continuous alcoholic fermentation assays were made with different concentrations of immobilized cells, as well as with different dilution rates. The obtained results are presented in Table 1.

The first two continuous fermentations were carried out with $60 \mathrm{~g}$ and $90 \mathrm{~g}$ of grape stems. The other two fermentation assays were carried out with $125 \mathrm{~g}$ and $260 \mathrm{~g}$ of grape skins, respectively. In all assays with grape skins these were hold down with small amount of grape stems, as well as with an iron net. Firstly the packed bed reactor worked in batch mode, with complex medium, for better cell immobilization. After $48 \mathrm{~h}$, the reactor was switched to a continuous mode of operation.

The assays with $60 \mathrm{~g}$ of immobilized grape stems were conducted with three different dilution rates $\left(0.05 \mathrm{~h}^{-1}, 0.10 \mathrm{~h}^{-1}\right.$ and $0.20 \mathrm{~h}^{-1}$ ), the most effective conditions being obtained at $D=0.05 \mathrm{~h}^{-1}$. At this dilution rate, the ethanol production ( $\left.6 \mathrm{vol} \%\right)$ showed the best values compared to the two other dilution rates used. The residual glucose concentration was rather high, $42 \mathrm{~g} / \mathrm{L}$, and the amount of immobilized cells was low $\left(X_{\mathrm{im} . \mathrm{T}}=5.1 \mathrm{mg} / \mathrm{g}\right.$; $X_{\text {im.B }}=7.7 \mathrm{mg} / \mathrm{g}$ ). Taking into account these results, the subsequent assay was carried out with $90 \mathrm{~g}$ of grape stems at $D=0.05 \mathrm{~h}^{-1}$. In this assay the initial sugar concentration was increased to $200 \mathrm{~g} / \mathrm{L}$, which theoretically would give an alcoholic strength to the final product of about $13 \mathrm{vol} \%$ However, the obtained results for alcoholic strength (4.3 vol\%) were very low, which are in agreement with the high final glucose concentration observed $(130 \mathrm{~g} / \mathrm{L})$.

To overcome this problem, grape skins were used as support material in a new series of continuous AF assays. In the first assay the total mass of the support was set to $125 \mathrm{~g}$ to obtain higher concentrations of immobilized cells. The initial concentration of glucose was $200 \mathrm{~g} / \mathrm{L}$ and 5 different dilution rates were studied (Table 1). The best results for ethanol production $(11.7 \mathrm{vol} \%)$ were registered for $D=0.038 \mathrm{~h}^{-1}$. Good results were obtained also when the reactor was operated at $D=0.046 \mathrm{~h}^{-1}$. Nevertheless, the final concentration of glucose, $21 \mathrm{~g} / \mathrm{L}$, was still high (Table 1). The obtained quantities of immobilized cells $(205.8 \mathrm{mg} / \mathrm{g}$ on the top of the packed bed and $537.2 \mathrm{mg} / \mathrm{g}$ at the bottom of the packed bed) were much higher than in the previous assay using $90 \mathrm{~g}$ of grape stems as support ( $8.3 \mathrm{mg} / \mathrm{g}$ and $19.4 \mathrm{mg} / \mathrm{g}$, on top and bottom of the packed bed, respectively).

In attempt to reach higher immobilized cell load in the reactor and to decrease the final glucose concentration, the last continuous alcoholic fermentations were carried out with $260 \mathrm{~g}$ of grape skins, using the total bed reactor volume, i.e. $1506 \mathrm{~mL}$. Initially, the two first assays with complex medium were conducted with low concentration of glucose, $120 \mathrm{~g} / \mathrm{L}$, as it was observed previously (data not shown) that cell adhesion to the support, i.e. immobilization, is faster. However, at initial sugar concentration of $120 \mathrm{~g} / \mathrm{L}$, the obtained results for ethanol production were low, $7.1 \mathrm{vol} \%$ for $D=0.038 \mathrm{~h}^{-1}$ and $8.6 \mathrm{vol} \%$ for $D=0.046 \mathrm{~h}^{-1}$. For to reach a higher load of immobilized yeast cells, the initial glucose concentration was finally increased to $200 \mathrm{~g} / \mathrm{L}$. In result, the ethanol production increased as follows: $11.2 \mathrm{vol} \%$ for $D=0.046 \mathrm{~h}^{-1}$ and $12.7 \mathrm{vol} \%$ for $D=0.038 \mathrm{~h}^{-1}$.

As the reactor operation remain stable for more than 1 month (since the beginning of the assay with $260 \mathrm{~g}$ of grape skins) the 
Table 1

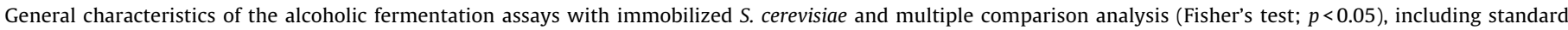
deviation $(s d)$.

\begin{tabular}{|c|c|c|c|c|c|c|c|c|c|c|c|c|}
\hline Support & $m(\mathrm{~g})$ & Media & $t(\mathrm{~d})$ & $D\left(\mathrm{~h}^{-1}\right)$ & $C_{\text {gl.in }}(\mathrm{g} / \mathrm{L})$ & $C_{\text {gl.fin }}(\mathrm{g} / \mathrm{L})$ & $C_{\text {et }}(\mathrm{vol} \%)$ & $s d$ & $X_{\text {im.T }}(\mathrm{mg} / \mathrm{g})$ & $s d$ & $X_{\text {im.B }}(\mathrm{mg} / \mathrm{g})$ & $s d$ \\
\hline \multirow[t]{4}{*}{ Grape stems } & \multirow[t]{3}{*}{60} & $C$ & 5 & 0.050 & 120 & 42 & $6.0^{\mathrm{fg}}$ & 0.3 & \multirow[t]{3}{*}{5.1} & \multirow[t]{3}{*}{2.8} & \multirow[t]{3}{*}{7.7} & \multirow[t]{3}{*}{3.1} \\
\hline & & C & 2 & 0.100 & 120 & 92 & $2.1^{\mathrm{h}}$ & 0.1 & & & & \\
\hline & & $C$ & 1 & 0.200 & 120 & 110 & $1.0^{\mathrm{h}}$ & 0.0 & & & & \\
\hline & 90 & C & 25 & 0.050 & 200 & 130 & $4.3^{g}$ & 0.0 & 8.3 & 2.4 & 19.4 & 0.5 \\
\hline \multirow[t]{10}{*}{ Grape skins } & \multirow[t]{5}{*}{125} & C & 7 & 0.038 & 200 & 24 & $11.7^{\mathrm{ab}}$ & 0.3 & \multirow[t]{5}{*}{205.8} & \multirow[t]{5}{*}{12.2} & \multirow[t]{5}{*}{537.2} & \multirow[t]{5}{*}{54.6} \\
\hline & & C & 7 & 0.046 & 200 & 21 & $11.4^{\mathrm{bc}}$ & 0.9 & & & & \\
\hline & & C & 42 & 0.050 & 200 & 29 & $9.9^{\mathrm{cd}}$ & 0.2 & & & & \\
\hline & & C & 43 & 0.058 & 200 & 36 & $11.1^{\mathrm{bc}}$ & 0.8 & & & & \\
\hline & & C & 6 & 0.100 & 200 & 90 & $8.6^{\text {de }}$ & 0.6 & & & & \\
\hline & \multirow[t]{5}{*}{260} & $C$ & 3 & 0.038 & 120 & 0 & $7.1^{\mathrm{ef}}$ & 0.2 & \multirow[t]{5}{*}{1476.8} & \multirow[t]{5}{*}{128.1} & \multirow[t]{5}{*}{2256.9} & \multirow[t]{5}{*}{18.9} \\
\hline & & C & 5 & 0.046 & 120 & 3 & $8.6^{\text {de }}$ & 0.6 & & & & \\
\hline & & C & 5 & 0.038 & 200 & 2 & $12.7^{\mathrm{a}}$ & 0.3 & & & & \\
\hline & & C & 19 & 0.046 & 200 & 42 & $11.2^{\mathrm{bc}}$ & 0.0 & & & & \\
\hline & & M & 47 & 0.038 & $200^{*}$ & 2 & $13.1^{\mathrm{a}}$ & 0.1 & & & & \\
\hline
\end{tabular}

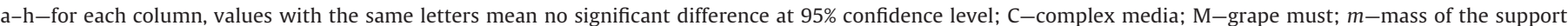

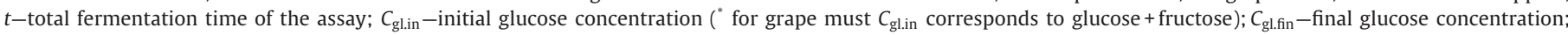
$X_{\mathrm{im} . \mathrm{T}}$-concentration of immobilized cells at the top of the reactor; $X_{\mathrm{im} . \mathrm{B}}$-concentration of immobilized cells at the bottom of the reactor.

Table 2

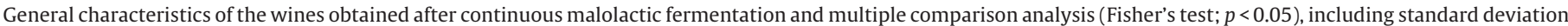
(sd).

\begin{tabular}{|c|c|c|c|c|c|c|c|}
\hline Fermentation & Medium & $\eta_{\text {mal.ac }}(\%)$ & $s d$ & $C_{\text {mal.ac }}(\mathrm{g} / \mathrm{L})$ & $s d$ & $C_{\text {lac.ac }}(\mathrm{g} / \mathrm{L})$ & $s d$ \\
\hline \multirow[t]{2}{*}{1} & Complex & $91^{\mathrm{a}}$ & 2.6 & $0.4^{\mathrm{b}}$ & 0.1 & $8.6^{\mathrm{a}}$ & 0.0 \\
\hline & wine ( $\mathrm{pH}$ 2.9) & $21^{\mathrm{b}}$ & 1.7 & $3.2^{\mathrm{a}}$ & 0.1 & $8.4^{\mathrm{a}}$ & 0.3 \\
\hline \multirow[t]{2}{*}{2} & Complex & $93^{\mathrm{a}}$ & 1.7 & $0.3^{b}$ & 0.1 & $5.8^{\mathrm{b}}$ & 0.6 \\
\hline & wine $(\mathrm{pH} 3.1)$ & $85^{\mathrm{a}}$ & 0.0 & $0.4^{\mathrm{b}}$ & 0.0 & $5.7^{\mathrm{b}}$ & 0.0 \\
\hline
\end{tabular}

a-c-for each column, values with the same letters mean no significant difference at 95\% confidence level.

complex medium was changed to grape must. At these conditions and after achieved the steady state, the obtained results showed improved ethanol production, $13.1 \mathrm{vol} \%$ The reactor operated with grape must for $47 \mathrm{~d}$. At a dilution rate of $0.038 \mathrm{~h}^{-1}$, the final glucose concentration reached low values of $2 \mathrm{~g} / \mathrm{L}$, i.e. a dry white wine was produced. Moreover, the concentration of immobilized cells calculated at the end of the fermentation demonstrated high cell load in the entire reactor ( $1476.8 \mathrm{mg} / \mathrm{g}$ on the top and $2256.9 \mathrm{mg} / \mathrm{g}$ on the bottom).

When comparing the results between assays one can observed the differences in ethanol production. The differences in ethanol production between the assays with yeast cells immobilized on grape stems or on grape skins are dependent on the used support [24]. While in the assays where the same support is used the differences in ethanol production are mainly due to the dilution rate used.

During the continuous alcoholic fermentation with immobilized cells in the packed bed reactor working at $D=0.038 \mathrm{~h}^{-1}$, the flow rate of wine production was $\approx 960 \mathrm{~mL} / \mathrm{d}$, being the AF completed in $26.3 \mathrm{~h}$. In our previous study using immobilized yeast cells on grape skins for wine production, in batch mode, at least $4 \mathrm{~d}$ were needed to complete the alcoholic fermentation in a 1 L container [29]. When compared to the results obtained in this study it is clear that continuous alcoholic fermentation with immobilized yeast cells are about 4 times more productive than fermentation in the batch mode.

\subsection{Continuous malolactic fermentations}

As far as we know there are only few studies of continuous malolactic fermentations with immobilized bacteria cells [22]. Based on the results obtained for the continuous alcoholic fermentation, continuous malolactic fermentations were also carried out with $260 \mathrm{~g}$ of support containing immobilized bacterial cells, operating at a dilution rate of $0.038 \mathrm{~h}^{-1}$. Firstly, $O$. oeni bacterial cells were allowed to immobilize in the previously sterilized grape skins, using complex medium. For screening the bacteria development and growth, samples were taken at different time periods. After $48 \mathrm{~h}$, the reactor was switched to the continuous mode of operation. Two continuous malolactic fermentations were carried out. For each fermentation assay, firstly the system was supplied with complex medium and then it was replaced by dry white wine (Table 2).

In the first fermentation, the malic acid conversion in continuous fermentation with complex medium was $91 \%$ (Table 2). However, when the wine was supplied a gradual decrease of the malolactic conversion was observed, possibly due to the low $\mathrm{pH}$ (2.9). At the 5 th day of fermentation, the malic acid conversion was $21 \%$ and after $17 \mathrm{~d}$ the malolactic fermentation stopped completely. These results are in agreement with those referred by Ribéreau-Gayon et al. [1], which stated a pH of 2.9 as the limit for the growth of lactic acid bacteria.

In the second continuous malolactic fermentation assay, the conversion of malic acid using complex medium reached $93 \%$. The higher $\mathrm{pH}$ value of the wine (3.1) in this assay facilitated the malolactic conversion (85\%). According to Ribéreau-Gayon et al. [1], at $\mathrm{pH} 3.2$ the bacterial growth is still very limited and malolactic fermentation only becomes possible at a $\mathrm{pH}$ of 3.3 or higher. However immobilized bacteria cells are more resistant against inhibitors $[21,29]$ and the $\mathrm{pH} 3.1$ was high enough for the immobilized bacteria cells to conduct successfully malolactic fermentation. In those conditions the used system gave high degradation of malic acid and long term operation stability (around 1 month).

\subsection{Integrated continuous winemaking}

This is a first attempt for developing an integrated continuous process of winemaking. Two assays of winemaking, integrating the two continuous processes were made (Fig. 1). The packed bed reactor with immobilized yeast cells was linked to the packed bed reactor with immobilized bacterial cells, using a kitasato flask as a 
Table 3

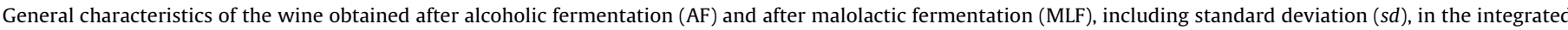
process of winemaking.

\begin{tabular}{|c|c|c|c|c|c|c|c|c|}
\hline & \multicolumn{4}{|c|}{ 1st assay (pH 2.9) } & \multicolumn{4}{|c|}{ 2nd assay ( $\mathrm{pH} 3.1$ ) } \\
\hline & $\mathrm{AF}$ & $s d$ & MLF & $s d$ & $\mathrm{AF}$ & $s d$ & MLF & $s d$ \\
\hline$C_{\text {mal.ac }}(\mathrm{g} / \mathrm{L})$ & 2.57 & 0.06 & 2.55 & 0.05 & 2.44 & 0.12 & 0.81 & 0.03 \\
\hline$\eta_{\text {mal.ac }}(\%)$ & & & 0.8 & 0.4 & & & 66.7 & 1.0 \\
\hline$C_{\text {acet.ac }}(\mathrm{g} / \mathrm{L})$ & 0.60 & 0.00 & 0.62 & 0.00 & 0.35 & 0.04 & 0.60 & 0.01 \\
\hline$C_{\text {lac.ac }}(\mathrm{g} / \mathrm{L})$ & 1.64 & 0.01 & 1.43 & 0.01 & 1.63 & 0.18 & 4.54 & 0.02 \\
\hline$C_{\mathrm{gl}}(\mathrm{g} / \mathrm{L})$ & 0.40 & 0.01 & 0.34 & 0.00 & 0.33 & 0.01 & 0.00 & 0.00 \\
\hline$C_{\mathrm{fr}}(\mathrm{g} / \mathrm{L})$ & 0.88 & 0.02 & 0.44 & 0.00 & 0.75 & 0.04 & 0.00 & 0.00 \\
\hline$C_{\text {et }}($ vol\%) & 12.7 & 0.0 & 12.9 & 0.2 & 12.2 & 0.33 & 11.5 & 0.0 \\
\hline $\mathrm{pH}$ & 2.9 & & nd & & 3.1 & & 3.3 & \\
\hline$T A(\mathrm{~g} / \mathrm{L})$ & nd & & nd & & 2.4 & & 0.2 & \\
\hline
\end{tabular}

nd-not determined; TA-total acidity, expressed as tartaric acid.

clarifier between them. The outflow of the first reactor, after sedimentation of yeast cells, was indeed the inflow of the second reactor (Fig. 1). The whole system was operating in continuous mode at a dilution rate of $0.038 \mathrm{~h}^{-1}$, using $260 \mathrm{~g}$ of grape skins as support material for cells immobilization. After reaching the steady state (fifth day of fermentation), the system was stable till the end of the study. The first assay was not successful as the wine produced in the first reactor had very low pH value of 2.9 (Table 3$)$. However, in the second assay the wine produced by AF had higher $\mathrm{pH}$ (3.1) resulting in a final wine with expected good characteristics.

Table 3 presents some general characteristics of the wine obtained in this integrated process. In the first integrated assay, the degradation of malic acid was very poor, $0.8 \%$. As mentioned before, the low $\mathrm{pH}$ value of the wine produced in the reactor with immobilized yeast cells could justify the results; additionally, the synergic effect of the high alcoholic strength might have influence. Here, the residual sugars, glucose and fructose, present after the alcoholic fermentation were further reduced during the MLF by $15 \%$ and $50 \%$, respectively. No changes in ethanol concentration were found, as expected [30].

In the second assay of the integrated process, the wine produced in the first packed reactor had a $\mathrm{pH}$ 3.1. As a result, the degradation of malic acid in the second reactor was much higher $66.7 \%$. In the total, $1.63 \mathrm{~g} / \mathrm{L}$ of malic acid was consumed by the immobilized bacteria cells, and $2.91 \mathrm{~g} / \mathrm{L}$ of lactic acid were produced. The system was able to metabolize malic acid, being the results comparable with previous studies [20]. The concentration of sugars, glucose and fructose, also decreased and may have been partially converted to lactic acid. According to Genisheva et al. [21] bacterial cells immobilized on grape skins were able to diminish the concentration of malic acid from $50 \%$ to $87 \%$ in $17 \mathrm{~d}$ of fermentation in batch mode of operation. In the present study, after the system reached the steady state, the continuous malolactic fermentation using immobilized bacterial cells converted about $67 \%$ of malic acid at a flow rate of $960 \mathrm{~mL} / \mathrm{d}$ and a fermentation time of $26.3 \mathrm{~h}$ (i.e. $D=0.038 \mathrm{~h}^{-1}$ ). These results showed that MLF was about 17 times more efficient when conducting in the continuous mode of operation.

The low concentrations of residual sugars were completely exhausted during MLF, while the ethanol concentration did not change. Acetic acid is the most important volatile acid produced during MLF. Additionally, concentrations of this acid between $0.2 \mathrm{~g} / \mathrm{L}$ and $0.6 \mathrm{~g} / \mathrm{L}$ contributes to the complexity of the wine aroma $[31,32]$. In the present study, the concentration of acetic acid increased from $0.35 \mathrm{~g} / \mathrm{L}$ to $0.60 \mathrm{~g} / \mathrm{L}$ after MLF (Table 2). In fact it is well known that the concentration of acetic acid normally increased $0.1 \mathrm{~g} / \mathrm{L}$ to $0.2 \mathrm{~g} / \mathrm{L}$ after MLF [32], which corroborates the obtained results. The partial consumption of citric acid (results not shown) may also contribute to obtained results. The limit for volatile acidity in white wines, which comprises essentially acetic acid, is $1.2 \mathrm{~g} / \mathrm{L}$ [26].

In order to obtain a better comparison between the wine produced in continuous alcoholic fermentation and the wine obtained after continuous malolactic fermentation, in the integrated system, a complete characterization of the products regarding aroma volatile compounds was made. The obtained results are presented at Tables 4 and 5. In total, 8 major volatile compounds and 19 minor volatile compounds were identified and quantified by GC-FID and by GC-MS, respectively.

\subsection{Major volatile compounds}

From the 8 major volatile compounds analyzed only acetaldehyde and four higher alcohols demonstrated significant difference before and after malolactic fermentation (MLF). Moreover, four

Table 4

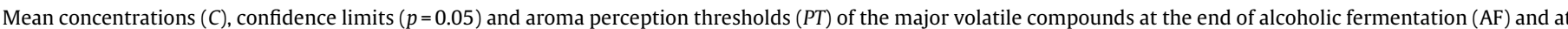
the end of the malolactic fermentation (MLF).

\begin{tabular}{|c|c|c|c|c|c|}
\hline \multirow[t]{2}{*}{ Compound } & \multicolumn{2}{|l|}{$\mathrm{AF}$} & \multicolumn{2}{|l|}{ MLF } & \multirow[t]{2}{*}{$P T(\mathrm{mg} / \mathrm{L})$} \\
\hline & $C(\mathrm{mg} / \mathrm{L})$ & \pm & $C(\mathrm{mg} / \mathrm{L})$ & \pm & \\
\hline Acetaldehyde & $20.9^{\mathrm{b}}$ & 5.7 & $30.7^{\mathrm{a}}$ & 7.4 & $10^{\Gamma}$ \\
\hline Ethyl acetate & $57.4^{\mathrm{a}}$ & 16.9 & $66.0^{\mathrm{a}}$ & 21.8 & 12.3 Д \\
\hline Methanol & $24.6^{\mathrm{a}}$ & 2.5 & $23.9^{\mathrm{a}}$ & 10.8 & $668^{\Gamma}$ \\
\hline \multicolumn{6}{|l|}{ Higher alcohols } \\
\hline 1-Propanol & $85.3^{\mathrm{a}}$ & 13.9 & $61.5^{\mathrm{b}}$ & 16.6 & $830^{\Gamma}$ \\
\hline 2-Methyl-1-propanol & $37.4^{\mathrm{a}}$ & 7.6 & $30.0^{\mathrm{b}}$ & 7.8 & $40^{\Gamma}$ \\
\hline 2-Methyl-1-butanol & $14.9^{\mathrm{a}}$ & 3.0 & $11.6^{\mathrm{b}}$ & 3.1 & \\
\hline 3-Methyl-1-butanol & $102.9^{\mathrm{a}}$ & 20.7 & $80.9^{\mathrm{b}}$ & 24.2 & $30^{\Gamma}$ \\
\hline 2-Phenylethanol & $6.6^{\mathrm{a}}$ & 1.1 & $5.7^{\mathrm{a}}$ & 3.3 & 14 Ж \\
\hline Total & 245.3 & 31.8 & 189.7 & 39.9 & \\
\hline
\end{tabular}

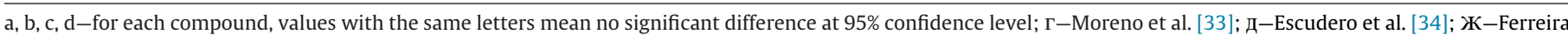
et al. [43]. 
Table 5

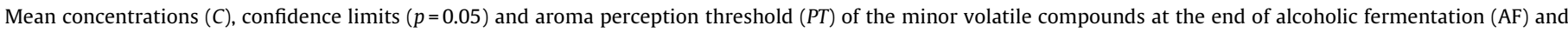
malolactic fermentation (MLF).

\begin{tabular}{|c|c|c|c|c|c|}
\hline \multirow[t]{2}{*}{ Compound } & \multicolumn{2}{|l|}{$\mathrm{AF}$} & \multicolumn{2}{|l|}{ MLF } & \multirow[t]{2}{*}{$P T(\mu \mathrm{g} / \mathrm{L})$} \\
\hline & $C(\mu \mathrm{g} / \mathrm{L})$ & \pm & $C(\mu \mathrm{g} / \mathrm{L})$ & \pm & \\
\hline \multicolumn{6}{|l|}{ Fatty acid ethyl esters } \\
\hline Ethyl butyrate & $186.5^{\mathrm{a}}$ & 65.9 & $148.7^{\mathrm{a}}$ & 13.9 & 20 Д \\
\hline Ethyl hexanoate & $758.6^{\mathrm{a}}$ & 78.6 & $545.3^{\mathrm{a}}$ & 35.5 & $14^{\Gamma}$ \\
\hline Ethyl octanoate & $257.7^{\mathrm{b}}$ & 13.7 & $551.9^{\mathrm{a}}$ & 47.9 & $5^{\Gamma}$ \\
\hline Ethyl decanoate & $142.4^{\mathrm{b}}$ & 43.9 & $222.0^{\mathrm{a}}$ & 41.1 & $200^{\Gamma}$ \\
\hline Total & 1345.2 & 112.4 & 1467.9 & 73.7 & \\
\hline \multicolumn{6}{|l|}{ Ethyl esters of organic acids } \\
\hline Ethyl lactate & $76.0^{\mathrm{a}}$ & 22.1 & $32.3^{b}$ & 7.8 & $100,000 \%$ \\
\hline Diethyl succinate & nd & & nd & & $100,000^{Ж}$ \\
\hline \multicolumn{5}{|l|}{ Acetates of higher alcohols } & \\
\hline 3-Methylbutyl acetate & $2050.6^{\mathrm{a}}$ & 309.1 & $1371.9^{\mathrm{b}}$ & 161.6 & $30 Ж$ \\
\hline Hexyl acetate & $57.2^{\mathrm{a}}$ & 15.1 & $37.1^{\mathrm{b}}$ & 10.8 & $1000^{\mathrm{M}}$ \\
\hline 2-Phenylethyl acetate & $170.4^{\mathrm{a}}$ & 19.8 & $114.4^{\mathrm{b}}$ & 3.1 & $250 Ж$ \\
\hline Total & 2278.2 & 310.1 & 1523.4 & 162.0 & \\
\hline \multicolumn{6}{|l|}{ Volatile phenols } \\
\hline 4-Vinylguaiacol & $4.4^{\mathrm{a}}$ & 2.9 & $1.7^{\mathrm{b}}$ & 0.6 & $130^{\phi}$ \\
\hline 4-Vinylphenol & nd & & nd & & $180^{\phi}$ \\
\hline Total & 4.4 & 2.9 & 1.7 & 0.6 & \\
\hline \multicolumn{6}{|l|}{ Volatile fatty acids } \\
\hline Butanoic acid & $36.5^{\mathrm{a}}$ & 12.6 & $33.2^{\mathrm{a}}$ & 5.2 & $173^{\Gamma}$ \\
\hline Hexanoic acid & $688.4^{\mathrm{a}}$ & 170.0 & $603.4^{\mathrm{a}}$ & 45.0 & $420^{\Gamma}$ \\
\hline Octanoic acid & $2617.0^{\mathrm{a}}$ & 497.5 & $2382.3^{\mathrm{a}}$ & 185.2 & $500^{\Gamma}$ \\
\hline Decanoic acid & $420.9^{a}$ & 296.8 & $150.0^{\mathrm{b}}$ & 54.4 & $1000^{\Gamma}$ \\
\hline Dodecanoic acid & $64.9^{\mathrm{a}}$ & 10.5 & $6.8^{\mathrm{b}}$ & 2.4 & $10,000 Ж$ \\
\hline 2-Methylpropanoic acid & $26.7^{\mathrm{a}}$ & 7.5 & $22.1^{\mathrm{a}}$ & 1.9 & $2300^{\Gamma}$ \\
\hline $2+3$-Methylbutanoic acids & $35.8^{\mathrm{a}}$ & 8.5 & $30.9^{\mathrm{a}}$ & 8.9 & $33.4^{\Gamma}$ \\
\hline Total & 3890.2 & 604.1 & 3228.7 & 198.5 & \\
\hline
\end{tabular}

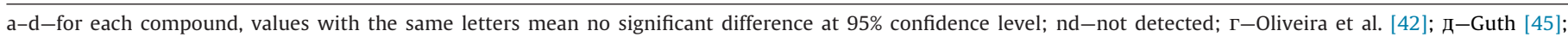
Ж-Moreno et al. [33]; M-Chaves et al. [46]; ф-Boidron et al. [47].

compounds were found in concentrations above their perception thresholds for both samples, after AF and after MLF. Acetaldehyde increased significantly $(p<0.05)$ after MLF, which is in agreement with other published data $[20,30]$. However, in our study, acetaldehyde was found in much lower concentrations compared to other published results with immobilized bacterial cells conducting MLF in batch mode [20]. Nevertheless acetaldehyde was always found above its orthonasal perception threshold of $10 \mathrm{mg} / \mathrm{L}$ [33]. Ethyl acetate was also found, in all the samples, in concentrations above its perception threshold of $12.3 \mathrm{mg} / \mathrm{L}$ [34] and similar to other published results [16]. Ethyl acetate is considered an important contributor to the wine aroma. At low concentrations ( $\leq 100 \mathrm{mg} / \mathrm{L}$ ) this compound gives desirable "fruity" aromas to the wine; however, at higher concentrations it can impart "solvent" or "nail varnish-like" aromas [35]. Methanol is produced from the pectins of the skin of the grapes which undergo an enzymatic conversion [1]. Nevertheless the methanol concentrations found in wines produced with cells immobilized on grape skins were low $(24.6 \mathrm{~g} / \mathrm{L}$ after AF and $23.9 \mathrm{~g} / \mathrm{L}$ after MLF). Sipsas et al. [16], using a packed bed reactor in continuous mode, reported methanol concentrations two times higher than those found in the present study. Also Tsakiris et al. [36], using yeasts immobilized on raisins to carry out AF (in batch mode), found methanol concentrations $(93.2 \mathrm{~g} / \mathrm{L}$ and $86.5 \mathrm{~g} / \mathrm{L}$ ) 4 times higher when compared to the results obtained in the present study (Table 4).

Alcohols having more than two carbons and only one alcohol function are called higher alcohols. As higher alcohols are produced during AF, they are absent in grape must, but are found in wines in relatively high concentrations, reaching values above $100 \mathrm{mg} / \mathrm{L}$ [37]. The present study shows that higher alcohols (except 2phenylethanol) concentrations diminished significantly $(p<0.05)$ after MLF. Similar results were published by Agouridis et al. [30], using immobilized Lactobacillus casei cells on a delignified cellulosic material. The sum of the higher alcohols attained $245.3 \mathrm{mg} / \mathrm{L}$ after AF and $189.7 \mathrm{mg} / \mathrm{L}$ after MLF. These concentrations are in the normal range found in wines [37]. Excessive concentrations of higher alcohols may give "strong" and "pungent" notes to wines [38], while levels below $300 \mathrm{mg} / \mathrm{L}$ to $400 \mathrm{mg} / \mathrm{L}$ may impart "fruity" character $[39,40]$.

In wines, 1-propanol is normally found in concentrations between $1 \mathrm{mg} / \mathrm{L}$ and $50 \mathrm{mg} / \mathrm{L}$. However, in the present study 1 propanol was always found in concentrations higher than $50 \mathrm{mg} / \mathrm{L}$, but it never reached its perception threshold of $830 \mathrm{mg} / \mathrm{L}$ [33]. After AF, the wine had much higher concentration of 1-propanol and was found statistically different $(p<0.05)$ from wine after MLF. Additionally, it was found in much higher concentrations than those reported by Sipsas et al. [16], $23 \mathrm{mg} / \mathrm{L}$, in white wines produced continuously in a packed bed reactor with cells immobilized on gluten pellets.

The formation of higher alcohols is connected to the amino acids catabolism (Ehrlich pathway) and to the sugar metabolism of yeasts [37]. The higher alcohol 3-methyl-1-butanol was present, in both samples, in concentrations over its perception threshold of $30 \mathrm{mg} / \mathrm{L}$ [33]. The sum of 2-methyl-1-butanol and 3-methyl-1-butanol (117.8 $\mathrm{mg} / \mathrm{L}$ ) before MLF was higher compared to other published results $(75 \mathrm{mg} / \mathrm{L})$ for wine produced in continuous packed bed reactor [16]. According to Vilanova and Oliveira [37], 2-methyl1-butanol and 3-methyl-1-butanol together with 2-phenylethanol are the higher alcohols that most contribute to the aroma of wine.

In general, factors that increase the fermentation rate, such as higher concentrations of yeast biomass, also increase the formation of higher alcohols. Moreover the content of higher alcohols 
of wine varies according to the fermentation conditions, especially the species of yeast used in the fermentation process [1].

\subsection{Minor volatile compounds}

From the 19 minor volatile compounds identified and quantified, 9 were found to be statistically different $(p<0.05)$ in wines before and after MLF.

Fatty acid ethyl esters are formed enzymatically in a reaction between ethanol and fatty acids [37,41]. Esters have similar olfactory notes bringing "fruity" and "pleasant" characteristics to the overall aroma of wines [37]. However, changes in ester concentrations during MLF are strain specific [35]. All fatty acid ethyl esters, except ethyl decanoate were found in the wine samples in concentration above their perception thresholds, after AF (Table 5). Moreover, ethyl octanoate and ethyl decanoate increased their concentration after MLF, fact that is in agreement with Lerm et al. [32].

Ethyl esters of organic acids are formed during wine ageing by chemical esterification between ethanol and organic acids [1,35]. The most abundant ethyl esters of organic acids use to be ethyl lactate and diethyl succinate, which may attain higher levels in wines [37]. However in our samples these two compounds were not detected (diethyl succinate) or were found in low concentrations (ethyl lactate) once the analyzed wines were very young. The perception thresholds of ethyl lactate and diethyl succinate are very high (Table 5) and only ethyl lactate may occasionally contribute to the wine aroma [41].

Acetates of higher alcohols decreased slightly after MLF. Isoamyl acetate was found in all wine samples in concentrations above its perception threshold of $30 \mu \mathrm{g} / \mathrm{L}$ [33]. According to Oliveira et al. [42], isoamyl acetate and 2-phenylacetate, together with the ethyl esters ethyl butyrate, ethyl hexanoate, ethyl octanoate and ethyl decanoate are the main contributors to the aroma of young wines. In our samples, these compounds, except 2-phenylacetate, were present in concentrations above their perception thresholds, indicating that the resulting wines may have "sweet" and "fruity" flavors.

Ethyl esters and acetates of higher alcohols, together, are very important for the flavor profile of fermented beverages, as the known synergic effect may reduce individual perception thresholds $[35,41]$.

The volatile phenol 4-vinylguiacol was found statistically different for wines after AF and after MLF, showing less concentration after MLF. It is known that the concentrations of 4-vinilguiacol and 4-vinylphenol use to increase after MLF, as a result of the degradation of some phenolic acids by bacteria [32]. However, MLF may have contradictory effect on the sensory character of wine. It depends on the bacteria strain used, the presence and availability of precursors, the wine type and the vinification conditions [32].

The volatile fatty acids hexanoic acid, octanoic acid and $2+3-$ methylbutanoic acids (only for wine after AF) were also found in all samples in concentrations above its perception thresholds of $420 \mu \mathrm{g} / \mathrm{L}, 500 \mu \mathrm{g} / \mathrm{L}$ and $33.4 \mu \mathrm{g} / \mathrm{L}$, respectively [43]. Although fatty acids are characterized by unpleasant notes (sweat, cheese), their flavor is essential to the aromatic equilibrium of wines [37,44].

\section{Conclusions}

Continuous fermentations are advantageous over batch fermentations as they have shorter fermentation times and higher productivities. Grape skins were found to be an appropriate support to be used in continuous alcoholic and malolactic fermentations. Immobilized cell systems on grape skins have an optimal mechanical stability for use in packed bed reactor in continuous mode of operation.

The integrated continuous process of winemaking gave good operational stability and promising results for further research The obtained results on aroma compounds, suggested that the produced wines had "fruity" and "fresh" flavor. Immobilized bacteria cell system was strongly influenced by the $\mathrm{pH}$ value of the media and further studies in this aspect are needed. However malolactic fermentation was successful and well conducted.

The continuous mode of operation to carry out AF and/or MLF, in a winemaking process, opens the possibility to modulate the final characteristics of the wine by simply adjusting the dilution rate.

\section{References}

[1] Ribéreau-Gayon P, Dubourdieu D, Donéche B, Lonvaud A. Handbook of enology, volume 2-the chemistry of wine. stabilization and treatments. Chichester: John Wiley \& Sons; 2006

[2] Margaritis A, Kilonzo PM. Production of ethanol using immobilized cell bioreactor systems. In: Nedovic V, Willaert R, editors. Applications of cell immobilisation biotechnology. The Netherlands: Springer; 2005. p. 375-405.

[3] Verbelen P, De Schutter D, Delvaux F, Verstrepen K, Delvaux FR. Immobilized yeast cell systems for continuous fermentation applications. Biotechnol Lett 2006;28:1515-25.

[4] Kourkoutas Y, Bekatorou A, Banat I, Marchant A, Koutinas AA. Immobilization technologies and support materials suitable in alcohol beverages production: a review. Food Microbiol 2004;21:377-97.

[5] Kourkoutas Y, Koutinas AA, Kanellaki M, Banat I, Marchant RM. Continuous wine fermentation using a psychrophilic yeast immobilized on apple cuts at different temperatures. Food Microbiol 2002;19:127-34.

[6] Kourkoutas Y, Douma M, Koutinas AA, Kanellaki M, Banat I, Marchant RM. Continuous winemaking fermentation using quince-immobilized yeast at room and low temperatures. Process Biochem 2002:39:143-8.

[7] Larachi F, Cassanello M, Laurent A, Midoux N, Wild G. Gas-liquid interfacial areas in three-phase fixed bed reactors. Chem Eng Process 1997;36:497-504.

[8] Mallios P Kourkoutas Y, Iconomopoulou M, Koutinas AA. Psarianos C, Marchant $\mathrm{R}$, Banat IMB. Low temperature wine-making using yeast immobilized on pear pieces. J Sci Food Agric 2004;84:1615-23.

[9] Reddy LVA, Reddy YHK, Reddy OVS. Wine production by guava piece immobilized yeast from Indian cultivar grapes and its volatile composition. Biotechnology 2006;5:449-54.

[10] Reddy L, Reddy Y, Reddy L, Reddy O. Wine production by novel yeast biocatalyst prepared by immobilization on watermelon (Citrullus vulgaris) rind pieces and characterization of volatile compounds. Process Biochem 2008;43:748-52.

[11] Kandylis P, Drouza C, Bekatorou A, Koutinas AA. Scale-up of extremely low temperature fermentations of grape must by wheat supported yeast cells. Bioresour Technol 2010;101:7484-91.

[12] Kandylis P, Mantzari A, Koutinas AA, Kookos IK. Modelling of low temperature wine-making, using immobilized cells. Food Chem 2012;133:1341-8.

[13] Kandylis P, Dimitrellou D, Koutinas AA. Winemaking by barley supported yeast cells. Food Chem 2012;130:425-31.

[14] Genisheva Z, Macedo S, Mussatto SI, Oliveira JM, Teixeira JA. Production of white wine by Saccharomyces cerevisiae immobilized on grape pomace. J Inst Brew 2012;118:163-73.

[15] Mallouchos A, Reppa P, Aggelis G, Kanellaki M, Koutinas AA, Komaitis M Grape skins as a natural support for yeast immobilization. Biotechnol Lett 2002:24:1331-5.

[16] Sipsas V, Kolokythas J, Kourkoutas Y, Plessas S, Nedovic VA, Kanellaki M. Comparative study of batch and continuous multi-stage fixed-bed tower (MFBT) bioreactor during wine-making using freeze-dried immobilized cells. J Food Eng 2009:90:495-503.

[17] Bakoyianis V, Koutinas AA, Agelopoulos K, Kanellaki M. Comparative study of kissiris, $\gamma$-alumina, and calcium alginate as supports of cells for batch and continuous wine-making at low temperatures. J Agric Food Chem 1997:45:4884-8.

[18] Loukatos P, Kiaris M, Ligas I, Bourgos G, Kanellaki M, Komaitis M, Koutinas AA. Continuous wine making by $\gamma$-alumina-supported biocatalyst. Appl Biochem Biotechnol 2000;89:1-13.

[19] Kosseva M, Beschkov V, Kennedy JF, Lloyd LL. Malolactic fermentation in Chardonnay wine by immobilised Lactobacillus casei cells. Process Biochem 1998;33:793-8.

[20] Agouridis N, Kopsahelis N, Plessas S, Koutinas A, Kanellaki M. Oenococcus oeni cells immobilized on delignified cellulosic material for malolactic fermentation of wine. Bioresour Technol 2008;99:9017-20.

[21] Genisheva Z, Mussatto SI, Oliveira JM, Teixeira JA. Malolactic fermentation of wines with immobilised lactic acid bacteria-Influence of concentration, type of support material and storage conditions. Food Chem 2013;138:1510-4.

[22] Crapisi A, Nuti MP, Zamorani A, Spettoli P. Improved stability of immobilized Lactobacillus sp. cells for the control of malolactic fermentation in wine. Am J Enol Vitic 1987;38:310-2.

[23] Brányik T, Silva DP, Vicente AA, Lehnert R, Almeida e Silva JB, Dostálek P Teixeira JA. Continuous immobilized yeast reactor system for complete beer 
fermentation using spent grains and corncobs as carrier materials. J Ind Microbiol Biotechnol 2006;33:1010-8.

[24] Genisheva Z, Mussatto SI, Oliveira JM, Teixeira JA. Evaluating the potential of wine-making residues and corn cobs as support materials for cell immobilization for ethanol production. Ind Crop Prod 2011;34:979-85.

[25] Clesceri LS, Greenberg AE, Trussel RR. Standard methods for the examination of water and wastewater. Washington: American Public Health Association; 1989.

[26] OIV. Compendium of international methods of analysis. Paris: International Organization of Vine and Wine; 2012.

[27] Oliveira JM, Faria M, Sá F, Barros F, Araújo IM. C 6 -alcohols as varietal markers for assessment of wine origin. Anal Chim Acta 2006;563:300-9.

[28] Olivares SE. Paquete de diseños experimentales. FAUANL. Versio'n 2.5. Mari'n, N.L.: Facultad de Agronomi'a de la UANL; 1994.

[29] Genisheva Z, Mussatto SI, Vilanova M, Oliveira JM, Teixeira JA. Impact of biocatalyst storage and $\mathrm{SO}_{2}$ concentration on wine quality. In: Consecutive batch fermentations of white grape must with immobilized yeasts on grape skins; 2013 (unpublished results).

[30] Agouridis N, Bekatorou A, Nigam P, Kanellaki M. Malolactic fermentation in wine with Lactobacillus casei cells immobilized on delignified cellulosic material. J Agric Food Chem 2005;53:2546-51.

[31] Bartowsky EJ, Henschke PA. Malolactic fermentation and wine flavour. Aust Grapegrow Winemak 1995;378:83-94.

[32] Lerm E, Engelbrecht L, Du Toit M. Malolactic fermentation: the ABC's of MLF. S Afr J Enol Vitic 2010;31:186-212.

[33] Moreno JA, Zea A, Moyano L, Medina M. Aroma compounds as markers of the changes in sherry wines subjected to biological ageing. Food Control 2005;16:333-8.

[34] Escudero A, Gogorza B, Melús MA, Ortín N, Cacho J, Ferreira V. Characterization of the aroma of a wine from Maccabeo. Key role played by compounds with low odour activity values. J Agric Food Chem 2004;52:3516-24.

[35] Sumby KM, Grbin PR, Jiranek V. Microbial modulation of aromatic esters in wine: current knowledge and future prospects. Food Chem 2010;121:1-16.
[36] Tsakiris A, Sipsas V, Bekatorou A, Mallouchos A, Koutinas AA. Red wine making by immobilized cells and influence on volatile composition. J Sci Food Agric 2004;82:1357-63.

[37] Vilanova M, Oliveira JM. Application of gas chromatography on the evaluation of grape and wine aroma in Atlantic viticulture (NW Iberian Peninsula). In: Salih B, Çelikbiçak Ö, editors. Chromatography in plant science, wine technology, toxicology and some specific applications. InTech; 2012. p. 109-46.

[38] Nykänen L. Formation and occurrence of flavor compounds in wine and distilled alcoholic beverages. Am J Enol Vitic 1986;37:84-96.

[39] Rapp A, Versini G. Influence of nitrogen compounds in grapes on aroma compounds of wines. In: Charalambous G, editor. Food flavors: generation, analysis and process influence. Eighth International Flavor Conference. Elsevier Science; 1995. p. 1659-94.

[40] Swiegers JH, Bartowsky EJ, Henschke PA, Pretorius IS. Yeast and bacterial modulation of wine aroma and flavor. Aust J Grape Wine Res 2005;11:139-73.

[41] Dubois P. Les arômes des vins et leurs defauts (cont.). Rev Fr Oenol 1994; $145: 27-40$

[42] Oliveira JM, Oliveira P, Baumes RL, Maia MO. Changes in aromatic characteristics of Loureiro and Alvarinho wines during maturation. J Food Comp Anal 2008;21:695-707.

[43] Ferreira V, López R, Cacho JF. Quantitative determination of the odorants of young red wines from different grape varieties. J Sci Food Agric 2000;80:1659-67.

[44] Etiévant PX. Wine. In: Maarse H, editor. Volatile Compounds in Foods and Beverages. New York: Marcel Dekker Inc.; 1991. p. 483-546.

[45] Guth H. Identification of character impact odorants of different white wine varieties. J Agric Food Chem 1997;45:3027-32.

[46] Chaves M, Zea L, Moyano L, Medina M. Changes in color and odorant compounds during oxidative aging of Pedro Ximenez sweet wines. J Agric Food Chem 2007;55:3592-8

[47] Boidron JN, Chatonnet P, Pons M. Influence du bois sur certaines substances odorantes des vins. Conn Vigne Vin 1988;22:275-94. 